\title{
Seven-layer and Two-layer Domestic Filters for the Removal of Nephrotoxic Constituents in CKDu prevalent Areas, Sri Lanka: Are these Viable Options?
}

\author{
M.I. Sudasinghe, W.B. Gunawardana, M.W. Jayaweera, R.A.T.N. Ranasinghe \\ and S.Y.S. Dulshan
}

\begin{abstract}
Consumption of water with nephrotoxic constituents is said to have caused the chronic kidney disease of unknown etiology $(\mathrm{CKDu})$ in Sri Lanka; hence removal of such constituents from potable water has received profound attention. Although seven-layer and two-layer filters have been introduced to the communities in the CKDu prevalent areas, the efficacy of such filters for removal of nephrotoxic constituents has not been adequately evaluated. This study investigates the efficacy of these two filters for improving drinking water quality in the presence of hardness, fluoride, aluminum, and cadmium. Feed water was synthesized with $353,143 \mathrm{mgL}^{-1}$ hardness, $1.7,0.9 \mathrm{mgL}^{-1}$ fluoride, 1.2, 1.3 $\mathrm{mgL}^{-1}$ aluminum and 1.1, $1.0 \mathrm{mgL}^{-1} \mathrm{cadmium}$ for seven-layer filter and $342,149 \mathrm{mgL}^{-1}$ hardness, $1.7,0.8$ $\mathrm{mgL}^{-1}$ fluoride, $1.5,1 \mathrm{mgL}^{-1}$ aluminum and $1.1,1.2 \mathrm{mgL}^{-1}$ cadmium for two-layer filter simulating wet (October, November) and extremely wet (December) seasons, respectively. Filtered water with the seven-layer filter contained 336, $146 \mathrm{mgL}^{-1}$ hardness, $1.8,1.0 \mathrm{mgL}^{-1}$ fluoride, $0.7,0.9 \mathrm{mgL}^{-1}$ aluminum, and $0.9,0.99 \mathrm{mgL}^{-1}$ cadmium after 60 - and 30-days of operation under wet and extreme wet seasons, respectively. Filtered water with the two-layer filter showed $332,149 \mathrm{mgL}^{-1}$ hardness, $0.6,1.4 \mathrm{mgL}^{-1}$ fluoride, $0.7,0.3 \mathrm{mgL}^{-1}$ aluminum, and $0.5,0.2 \mathrm{mgL}^{-1} \mathrm{cadmium}$ after 60 - and 30-day operation under wet and extreme wet seasons, respectively. The quality of the filtered water from both filters did not comply with the Sri Lanka Standards (SLS) drinking water quality guidelines. The XRD, FT-IR, ESEM-EDX analyses revealed the presence of calcium, magnesium, fluoride, and aluminum in various layers of filter media of both filters. Such constituents retained in the filter media leached out during filtration resulting in higher levels in the permeate. Hence, the use of seven-layer and two-layer filters does not seem to be a promising solution to remove nephrotoxic constituents present in water in CKDu prevalent areas.
\end{abstract}

Keywords: Adsorption, Aluminum, Cadmium, Fluoride, Hardness

\section{Introduction}

Chronic kidney disease of unknown etiology $(\mathrm{CKDu})$ has become a critical health concern in the agricultural areas of the dry zone in Sri Lanka [1]. The studies carried out to date on the etiology of $\mathrm{CKDu}$ have not underpinned any promising cause. Histopathology studies of $\mathrm{CKDu}$ patients showed tubule-interstitial nephritis, which is suggestive of a toxic etiology [2]. Various studies propose that the presence of hardness $(\mathrm{Hd})$, fluoride $(\mathrm{F})$, aluminum $(\mathrm{Al})$ and cadmium $(\mathrm{Cd})$ in drinking water, individually or in combination, could act as plausible causal factors for the occurrence of CKDu $[2,3,4]$. Our preliminary studies provide evidence of the presence of $\mathrm{Hd}, \mathrm{F}$ in elevated levels and $\mathrm{Al}$ and $\mathrm{Cd}$ in trace levels in groundwater, which is a primary source of drinking water in CKDu prevalent areas.

Fluoride has been reported as a constituent altering the activity of many mitochondria-rich cells, such as those of the human kidneys; hence, $\mathrm{F}$ has been implicated as a causal factor responsible for the occurrence of CKDu $[5,6]$. The combined effect of high $\mathrm{F}$ and Hd levels has suggested causing increased severity of

Mrs. M. I. Sudasinghe, B.Sc. (Ruhuna), M.Phil (Peradeniya), PhD candidate (Moratuwa), Department of Civil Engineering, University of Moratuwa.

Email:masdhu1638@gmail.com

Eng. (Dr.) W. B. Gunawardana, AMIE(SL), B.Sc. Eng. (Moratuwa), M. Eng. Str., M. Eng. (Auckland), PhD

(Auckland), Senior Lecturer, Department of Civil Engineering, University of Moratuwa.

Email:buddhikag@uom.lk

Eng. (Prof.) M. W. Jayaweera, C. Eng., MIE(SL), B.Sc.

Eng. (Moratuwa), PhD (Saitama), Professor in

Environmental Engineering, Department of Civil

Engineering, University of Moratuwa.

Email:mahesh@uom.lk

Eng. R.A.T.N. Ranasinghe, AMIE(SL), B.Sc.

Eng.(Moratuwa), Civil Engineer, Nawaloka Constructions (Pvt) Ltd., ITC Hotel Tower, 21, Galle Face Centre Road,

Colombo 01.

Email:devanstharaka@gmail.com

Eng. S. Y. S. Dulshan, AMIE(SL), B.Sc. Eng. (Moratuwa), Site Engineer, International Construction Consortium (Pvt) Ltd., 70, S. De. S. JayasingheMawatha, Kohuwala, Nugegoda.

Email:subashdulshan@gmail.com 
$\mathrm{CKDu}$ [4]. Further, the presence of high calcium (Ca) levels leading to high $\mathrm{Ca}$ activity in the presence of high $\mathrm{F}$ levels in groundwater has been suggested as another causal factor for $\mathrm{CKDu}$ [7]. The aluminofluoride complexes that form in the presence of both $\mathrm{F}$ and $\mathrm{Al}$ have been presumed to be of higher permeability through biological membranes compared to $\mathrm{Al}$ and $\mathrm{F}$ acting individually, thus could impose higher toxic effects to the kidney [5]. Long-term exposure to $\mathrm{Cd}$ present in the drinking water has been reported as a triggering factor causing chronic renal failure [3, 7]. Therefore, development of proper treatment techniques that can reduce $\mathrm{Hd}, \mathrm{F}, \mathrm{Al}$, and $\mathrm{Cd}$ present in drinking water to non-nephrotoxic levels is of utmost importance.

Seven-layer and two-layer filters have been introduced as water treatment techniques at the household level to the communities in the CKDu affected areas intending to reduce $\mathrm{Hd}, \mathrm{F}, \mathrm{Al}$, and $\mathrm{Cd}$ and provide good quality drinking water. However, the efficacy of these filters for the removal of these constituents has not been adequately evaluated. Therefore, this study investigates the efficacy of these two filters regarding $\mathrm{Hd}, \mathrm{F}, \mathrm{Al}$, and $\mathrm{Cd}$ removal.

\section{Materials and Method}

\subsection{Characterization of Groundwater in the CKDuPrevalent Areas}

Groundwater samples were collected from seven shallow wells located in the CKDu prevalent areas in Anuradhapura district during wet (October \& November) and extremely wet (December) seasons for analysis of $\mathrm{Hd}, \mathrm{F}, \mathrm{Al}$, and $\mathrm{Cd}$. F levels in the samples were analyzed by Ion Chromatography (Metrohm, 930 Compact IC Flex, Switzerland) with a mobile phase of $3.2 \mathrm{mmolL}^{-1} \mathrm{Na}_{2} \mathrm{CO}_{3}+1 \mathrm{mmolL}^{-1}$ $\mathrm{NaHCO}_{3}$ and a flow rate of $0.7 \mathrm{mLmin}^{-1}$. $\mathrm{Hd}$, Ca and magnesium $(\mathrm{Mg})$ levels were analyzed using the EDTA titrimetric method (EPA Method No. 130.2). Cd and Al levels in the samples were analyzed using Flame Atomic Absorption Spectroscopy (AAS: GBC 932 plus, Australia) with a minimum detection level of $0.01 \mathrm{mgL}^{-1}$ of Cd and $0.2 \mathrm{mgL}^{-1}$ of Al. Deionized water (Heal Force, SMART Ultra-pure water system, China) was used in all experiments. Table 1 shows the levels of the selected parameters in groundwater collected from the $\mathrm{CKDu}$ affected areas in Anuradhapura district during wet and extremely wet seasons and the minimum detection level of each parameter.

\subsection{Characterization of the Filter Media}

Morphology and elemental composition of filter media were analyzed by Environmental Scanning Electron Microscopy (ESEM- Carl Zeiss, EVO 18, Secondary Electron Microscope, Germany) coupled with Energy-Dispersive Xray Spectroscopy (EDX Z1 analyzer, USA). The different phases of minerals in the filter media were identified using the X-ray Powder Diffraction (XRD-D8, ECO, Advance Bruker Diffractometer with filtered $\mathrm{Cu} \mathrm{K \alpha}$ radiation, Germany). Fourier Transform-Infrared Spectroscopy (FT-IR, ALPHA Bruker, Germany) was performed in the adsorption mode at ambient temperature in the spectral range of $500-4,000 \mathrm{~cm}^{-1}$ to identify the various functional groups present in the filter media.

\subsection{Experiment Methodology}

Synthetic raw water samples were prepared in the laboratory to simulate the water quality in the wet and extremely wet seasons. $\mathrm{Hd}, \mathrm{F}, \mathrm{Al}$, and $\mathrm{Cd}$ levels in the respective solutions were decided based on the groundwater quality analysis and the reported values in the literature. The ranges of $\mathrm{Hd}, \mathrm{F}, \mathrm{Al}$, and $\mathrm{Cd}$ levels in well water have been reported in the literature, as 101921, 0.1-7.0, 0.001-1.5 and 0.0002-1.9 mg/L, respectively [2, 3, 4, 7]. Table 2 shows characteristics of the synthetic water samples prepared based on these values.

Eight litres $(8 \mathrm{~L})$ of distilled water were first passed through each filter unit to remove impurities present, if any. It is assumed that a family consists of four members with each having a per capita consumption of $2 \mathrm{~L}$ with the total water consumption amounting to $8 \mathrm{~L}$ per day. Therefore, a cumulative volume of $8 \mathrm{~L}$ of the synthetic water was passed through the filters simulating the daily demand.

After cleaning the filters, the synthetic water samples were passed through the two filters, and the filtrate was collected at predetermined time intervals to study the removal of $\mathrm{Hd}, \mathrm{F}, \mathrm{Al}$, and $\mathrm{Cd}$ by the two filters. During the first phase of the experiment, the filters were operated under the conditions of the wet season (Table 2) for two months. In the end, the second phase of the experiment was conducted under the conditions of the extremely wet season (Table 2) for one month. During the operation of the filter at each phase, the filtrate was collected at predetermined time intervals and analyzed for $\mathrm{Hd}, \mathrm{F}, \mathrm{Al}$, and $\mathrm{Cd}$. 
Table 1 - Constituent Concentrations in Groundwater during the Wet and Extremely Wet Seasons

\begin{tabular}{|c|c|c|c|c|c|c|c|c|}
\hline \multirow{2}{*}{ Parameter } & \multicolumn{2}{|c|}{ Extremely wet season } & \multicolumn{5}{|c|}{ Wet season } & \multirow{2}{*}{ MDL } \\
\hline & S1 & $\mathrm{S2}$ & S3 & S4 & S5 & S6 & S7 & \\
\hline Hardness $\left(\mathrm{mgL}^{-1}\right.$ as $\left.\mathrm{CaCO}_{3}\right)$ & 112 & 140 & 632 & 136 & 120 & 120 & 176 & 4 \\
\hline Fluoride $\left(\mathrm{mgL}^{-1}\right)$ & 0.8 & 0.7 & 3.2 & 2.8 & 2.8 & 0.7 & 0.7 & 0.05 \\
\hline Calcium $\left(\mathrm{mgL}^{-1}\right)$ & 50 & 52 & 40 & 392 & 545 & 544 & 579 & 1 \\
\hline Magnesium (mgL-1) & 28 & 3 & $<1$ & $<1$ & 26 & 17 & 14 & 1 \\
\hline Aluminum $\left(\mathrm{mgL}^{-1}\right)$ & $<0.2$ & $<0.2$ & $<0.2$ & $<0.2$ & $<0.2$ & $<0.2$ & $<0.2$ & 0.2 \\
\hline Cadmium $\left(\mathrm{mgL}^{-1}\right)$ & $<0.2$ & $<0.2$ & $<0.2$ & $<0.2$ & $<0.2$ & $<0.2$ & $<0.2$ & 0.2 \\
\hline $\mathrm{pH}$ & 6.7 & 7.2 & 6.9 & 6.8 & 6.8 & 7.3 & 7.5 & 0.001 \\
\hline
\end{tabular}

MDL - Minimum detection level; S - sample

Table 2 - Characteristics of Synthetic Water Samples Used in the Experiment

\begin{tabular}{|l|c|c|c|c|}
\hline \multirow{2}{*}{ Parameter } & \multicolumn{2}{|c|}{ Two-layer filter unit } & \multicolumn{2}{c|}{ Seven-layer filter unit } \\
\cline { 2 - 5 } & $\begin{array}{c}\text { Wet season } \\
\text { (October, } \\
\text { November) }\end{array}$ & $\begin{array}{c}\text { Extremely wet } \\
\text { season } \\
\text { (December) }\end{array}$ & $\begin{array}{c}\text { Wet season } \\
\text { (October, } \\
\text { November) }\end{array}$ & $\begin{array}{c}\text { Extremely } \\
\text { wet season } \\
\text { (December) }\end{array}$ \\
\hline Hardness (mgL-1 as CaCO $_{3}$ ) & 342 & 149 & 353 & 143 \\
\hline Calcium (mgL-1) & 122 & 43 & 101 & 40 \\
\hline Magnesium (mgL-1) & 38 & 10 & 24 & 11 \\
\hline Fluoride (mgL-1) & 1.7 & 0.8 & 1.7 & 0.9 \\
\hline Aluminum (mgL-1) & 1.1 & 1.2 & 1.1 & 1.0 \\
\hline Cadmium (mgL-1) & 1.5 & 1 & 1.2 & 1.3 \\
\hline $\mathrm{pH}$ & 6.5 & 6.5 & 6.5 & 6.5 \\
\hline
\end{tabular}

The percentage removals of constituents by two filters were compared with drinking water guideline values (SLS 614:2013) (Hd - $250 \mathrm{mg} / \mathrm{L}$, $\mathrm{F}-1.0 \mathrm{mg} / \mathrm{L}, \mathrm{Al}-0.2 \mathrm{mg} / \mathrm{L}$ and $\mathrm{Cd}-0.003$ $\mathrm{mg} / \mathrm{L}$ ) to investigate their efficacy in the removal of $\mathrm{Hd}, \mathrm{F}, \mathrm{Al}$, and $\mathrm{Cd}$.

\section{Results and Discussion}

\subsection{Characterization of Filter Media \\ Seven-layer filter unit}

The seven-layer filter unit was composed of a micro-ceramic filter dome, activated carbon layer, mineral sand layer, silica sand layer, silver impregnated granular activated carbon layer, far-infrared balls layer, and mineral stones layer. Figure $1(\mathrm{a}-\mathrm{g})$ depicts the XRD pattern of the seven layers. The micro-ceramic filter dome (Figure 1a) comprised 2-Thiohydantoin $\left(\mathrm{C}_{3} \mathrm{H}_{4} \mathrm{~N}_{2} \mathrm{OS}\right)$, Wollastonite $\left(\mathrm{CaSiO}_{3}\right)$, Lapacol $\left(\mathrm{C}_{15} \mathrm{H}_{14} \mathrm{O}_{3}\right)$ and Anorthite $\left(\mathrm{CaAl}_{2} \mathrm{Si}_{2} \mathrm{O}_{8}\right.$ Feldspar mineral). 2-Thiohydantoin [8] and Lapachol [9] have been widely used as the antimicrobial (antifungal, antibacterial and antiviral) agent. Wollastonite is one of industrially synthesized minerals, which is used to remove ammonia and phosphorus in water [10]. Anorthite acts as a good source of micronutrient [11].
The ESEM-EDX analyses (Figure 2a) of the micro-ceramic filter dome also confirm the availability of silicon (Si) (35.6\%), $\mathrm{Al}(6.7 \%), \mathrm{Ca}$ $(9.5 \%)$, potassium $(\mathrm{K})(2.2 \%)$ and oxygen $(\mathrm{O})$ $(46.0 \%)$. FT-IR pattern (Figure 3 ) shows peaks at $1017 \mathrm{~cm}^{-1}, 915 \mathrm{~cm}^{-1}, 642 \mathrm{~cm}^{-1}, 535 \mathrm{~cm}^{-1}$ assigned to in-plane $\mathrm{Si}-\mathrm{O}-\mathrm{Si}$ stretching, the Al-O-Al bending vibration, the $\mathrm{Al}-\mathrm{O}$ coordination and the $\mathrm{Si}-\mathrm{O}$ asymmetrical bending vibration, respectively [12].

The XRD patterns of the activated carbon layer (Figure 1b) and silver impregnated granular activated carbon layer (Figure 1e) illustrate a prominent peak at $26.6^{\circ}$ and the silicon dioxide, the quartz, and a graphitic structure such as Dichloroglyoxime $\left(\mathrm{C}_{2} \mathrm{H}_{2} \mathrm{Cl}_{2} \mathrm{~N}_{2} \mathrm{O}_{2}\right)$, 4-butyl-1, 2diphenyl pyrazolidine-3 and 5-dione $\left(\mathrm{C}_{19} \mathrm{H}_{20} \mathrm{~N}_{2} \mathrm{O}_{2}\right)$. The ESEM-EDX analyses (Figure $2 \mathrm{~b})$ confirm the presence of $\mathrm{Si}(3.8 \%)$, carbon (C) $(80.5 \%)$ and $\mathrm{O}(15.7 \%)$ on the surface. FT-IR analysis (Figure 3 ) of the activated carbon and silver impregnated granular activated carbon layers shows a broad peak at the fingerprint region appearing at $1300-1000 \mathrm{~cm}^{-1}$. The peaks are ascribed to all carbon samples, and others could be ascribed to a mixed combination of $\mathrm{C}$ $\mathrm{C}, \mathrm{C}=\mathrm{C}, \mathrm{C}-\mathrm{H}$ stretches and $\mathrm{C}-\mathrm{CH}$ rocking vibrations [13] and a prominent peak at $532 \mathrm{~cm}^{-1}$ may be due to Phthalic acid [14]. 
Mineral sand and mineral stones layers show similar XRD patterns (Figures $1 \mathrm{c}$ and 1g) confirming that these two layers are composed of the same mineral type. Two prominent peaks at $26.6^{\circ}$ and $27.5^{\circ}$ and different crystalline phases of the minerals such as the Quartz $\left(\mathrm{SiO}_{2}\right)$, Albite $\left(\mathrm{NaAlSi}_{3} \mathrm{O}_{8}\right)$, Microcline $\left(\mathrm{KAlSi}_{3} \mathrm{O}_{8}\right)$, Magnesium carbon arsenide $\left(\mathrm{MgCAs}_{2}\right)$, the Hexamethylene tetra Selenafulvaleneperfluoro tetra cyanoquinodi-methane $\left(\mathrm{C}_{24} \mathrm{H}_{12} \mathrm{~F}_{4} \mathrm{~N}_{4} \mathrm{Se}_{4}\right)$ were observed.
The XRD pattern (Figure 1d) of the silica sand layer shows a prominent peak at $29.4^{\circ}$, and Ferro-gedrite $\left(\mathrm{Fe}_{5} \mathrm{Al}_{4} \mathrm{Si}_{6} \mathrm{O}_{22}(\mathrm{OH})_{2}\right)$ was identified as the principal mineral in the crystalline phase. The ESEM-EDX analyses (Figure 2d) also show that the surface of the silica sand is mainly composed of Si $(0.3 \%)$, Ca $(44.1 \%), C(7.3 \%)$ and $\mathrm{O}(48.2 \%)$. FT-IR peaks (Figure 3 ) were observed at $535 \mathrm{~cm}^{-1}$ as $\mathrm{Si}-\mathrm{O}$ asymmetrical bending vibration, at $642 \mathrm{~cm}^{-1}$ as $\mathrm{Al}-\mathrm{O}$ coordination vibration, at $738 \mathrm{~cm}^{-1}$ as symmetric $\mathrm{Si}-\mathrm{O}$
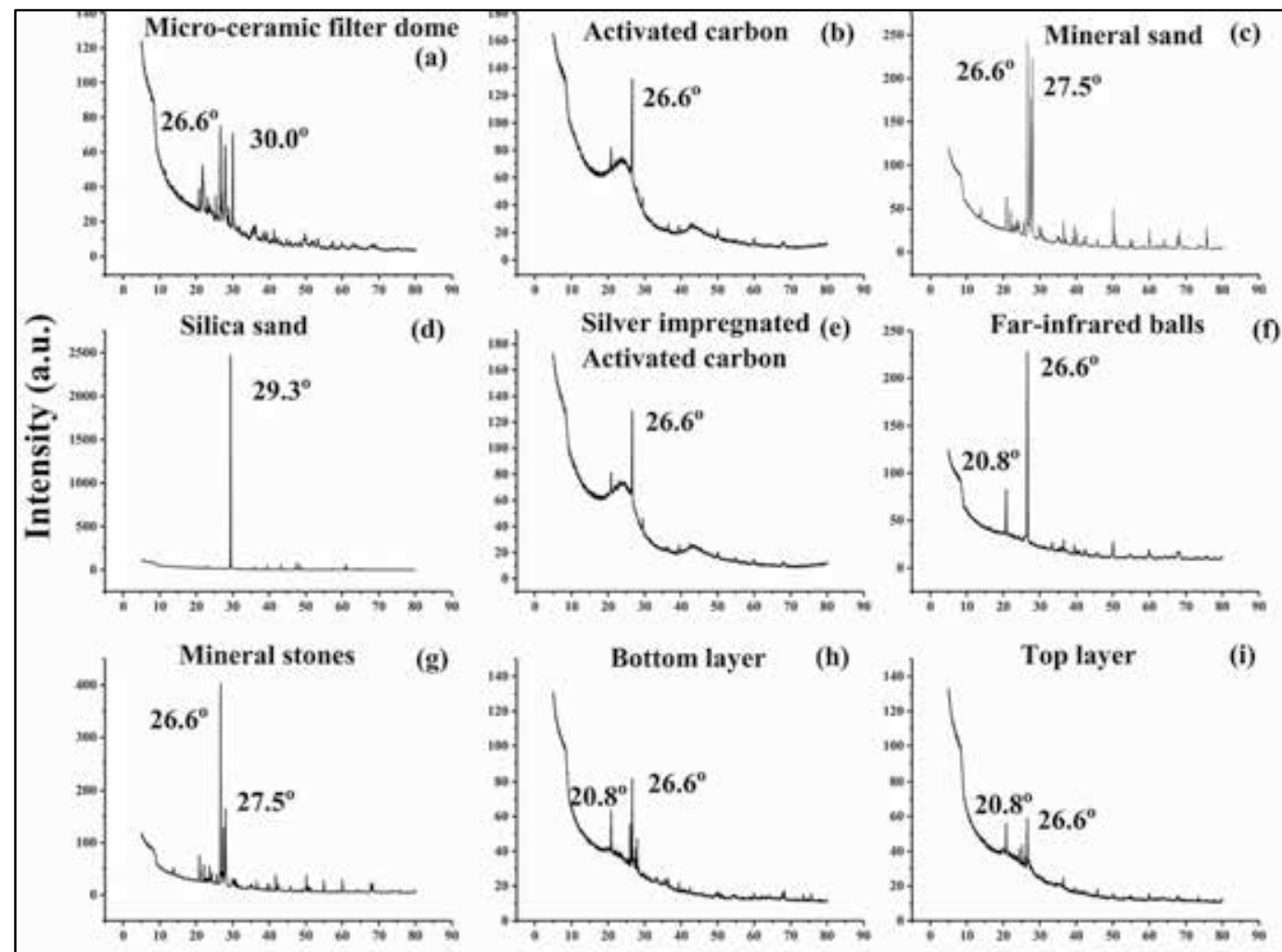

\section{Theta}

Figure 1 - XRD Pattern of Seven-layer Filter Media (a-g) and Two-layer Filter Media (h and i) Note(a) Micro-ceramic Filter Dome, (b) Activated Carbon, (c) Mineral Sand, (d) Silica Sand, (e) Silver Impregnated Granular Activated Carbon, (f) Far - infrared Balls, (g) Mineral Stones, (h) Bottom Layer and (i) Top Layer

The ESEM-EDX analyses (Figure 2c) confirm the presence of Si $(28.6 \%)$, Al (12.2\%), sodium (Na) $(7.1 \%), \mathrm{K}(1.2 \%)$, iron $(\mathrm{Fe})(0.9 \%), \mathrm{Ca}(3,4 \%)$ and $\mathrm{O}(46.5 \%)$ on the surface. FT-IR analysis (Figure 3) shows the peak at $535 \mathrm{~cm}^{-1}$ due to $\mathrm{Si}-\mathrm{O}$ asymmetrical bending vibration, at $695 \mathrm{~cm}^{-1}$ due to the $\mathrm{Si}-\mathrm{O}$ symmetrical bending vibration, at $775 \mathrm{~cm}^{-1}$ due to Si-O symmetrical stretching vibration [15], and at $1037 \mathrm{~cm}^{-1}$ due to Si-O-Si symmetrical stretching vibration [16]. Peaks at $3695 \mathrm{~cm}^{-1}, 3670 \mathrm{~cm}^{-1}, 3650 \mathrm{~cm}^{-1}$ and $3620 \mathrm{~cm}^{-1}$ assigned to in-phase and out of phase motion modes and the stretching vibration of inner surface $\mathrm{OH}$ groups were pronounced [12]. vibration, at $872 \mathrm{~cm}^{-1}$ due to $\mathrm{Fe}-\mathrm{Al}-\mathrm{OH}$ vibration and at $1395 \mathrm{~cm}^{-1}$ as asymmetric vibration of $\mathrm{COO}^{-}$groups [15]. Weak broad bands at 3440 and $3435 \mathrm{~cm}^{-1}$ correspond to overlapping of $\mathrm{O}-\mathrm{H}$ stretching band of hydrogen-bonded water molecules (H-O-H...H), as the Si-O-H stretching of surface silanol hydrogen-bonded water molecules $\left(\mathrm{Si}-\mathrm{O}-\mathrm{H} . . . \mathrm{H}_{2} \mathrm{O}\right)$ [17].

The XRD pattern of far-infrared balls shows (Figure 1f) the silicon dioxide (alpha-SiO${ }_{2}$ ), Dichloroglyoxime $\left(\mathrm{C}_{2} \mathrm{H}_{2} \mathrm{Cl}_{2} \mathrm{~N}_{2} \mathrm{O}_{2}\right)$, Quartz $\left(\mathrm{SiO}_{2}\right)$ and 4-butyl 1, 2-di-phenylpyrazolidine3, 5dione $\left(\mathrm{C}_{19} \mathrm{H}_{20} \mathrm{~N}_{2} \mathrm{O}_{2}\right)$. Dichloroglyoxime shows remarkable activity against gram-negative and positive bacteria and yeast [18]. ESEM-EDX 
analyses (Figure 2e) show the presence of $\mathrm{Si}$ $(0.6 \%), \mathrm{C}(88.3 \%), \mathrm{Al}(0.5 \%)$, sulphur (S) (0.2\%) and $\mathrm{O}(10.3 \%)$. The FT-IR bands (Figure 3) around $3400-3700 \mathrm{~cm}^{-1}$ are assigned to the stretching vibration of $\mathrm{Si}-\mathrm{O}-\mathrm{H}$ group and $\mathrm{H}-\mathrm{O}-$
$\mathrm{H}$ molecules [16]. The peak at $1055 \mathrm{~cm}^{-1}$ is attributed to stretching vibration of symmetric $\mathrm{Si}-\mathrm{O}-\mathrm{Si}$, and peaks at $789 \mathrm{~cm}^{-1}, 646 \mathrm{~cm}^{-1}$, and $610 \mathrm{~cm}^{-1}$ are assigned toa motion of $\mathrm{Si}$ atoms [19].

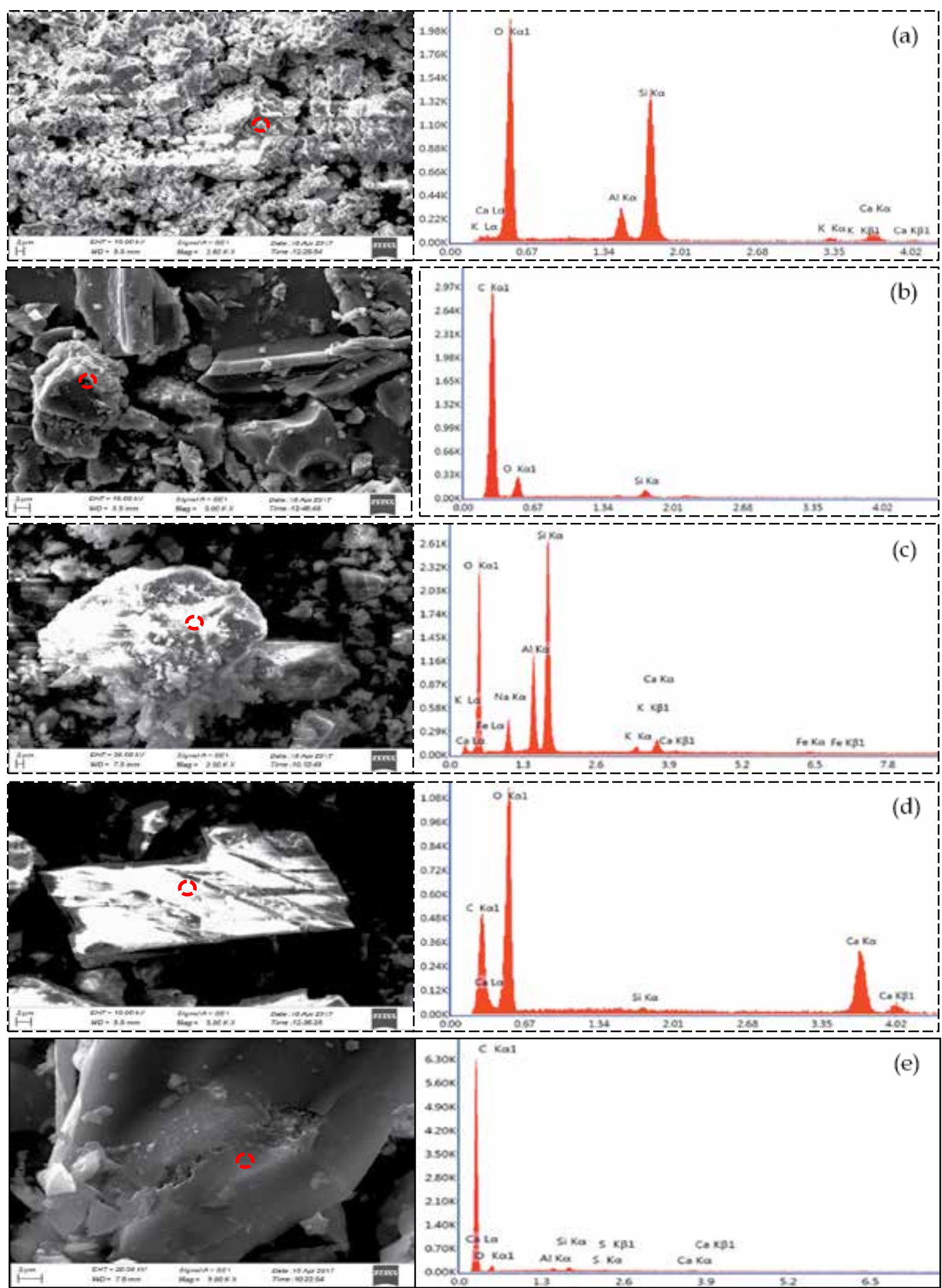

Figure 2 - ESEM-EDX Analysis of Seven-layer Filter (a) Micro-ceramic Filter Dome, (b) Activated Carbon and Silver Impregnated Granular Activated Carbon, (c) Mineral Sand, and Mineral stones (d) Silica Sand, and (e) Far-infrared Balls. 


\section{Two-layer filter unit}

Figure $1 \mathrm{~h}$ shows the XRD pattern of the bottom layer, which mainly consists of different crystalline phases such as quartz $\left(\mathrm{SiO}_{2}\right)$, albite $\left(\mathrm{NaAlSi}_{3} \mathrm{O}_{8}\right)$, hydrogen aluminum silicate $\left(\mathrm{H}_{3}\left(\mathrm{Al}_{3} \mathrm{Si}_{93}\right), \mathrm{O}_{192}\right)$ and the derivatives of organic salicylic acid such as 2-hydroxy-5-((2nitrophenyl) azo), -2-hydroxybenzoic acid and 2-Hydroxy-5-((2-nitrophenyl) azo) salicylic acid $\left(\mathrm{C}_{13} \mathrm{H}_{9} \mathrm{~N}_{3} \mathrm{O}_{5}\right)$. Quartz-type mineral shows peaks at $20.8^{\circ}, 26.67^{\circ}$ (Figure 1h) and Albite is one of the feldspar type minerals, which shows peaks at $27.52^{\circ}$ and $27.95^{\circ}$. Hydrogen tecto-alumo-silicate and Hydrogen aluminum silicate are also found by the XRD analysis. ESEM-EDX analyses (Figure 4a) of the bottom layer confirm the availability of $\mathrm{O}(45.8 \%), \mathrm{F}(1.2 \%), \mathrm{Al}(20.7 \%), \mathrm{Si}$ $(31.9 \%)$ and Phosphorus (P) (0.4\%). FT-IR absorption bands (Figure 5) were observed in the range 650 to $1200 \mathrm{~cm}^{-1}$ and are due to the Si$\mathrm{O}-\mathrm{Si}$ bending and stretching vibration, respectively, and the sharp peak at $800 \mathrm{~cm}^{-1}$ is due to symmetric stretching of $\mathrm{Si}-\mathrm{O}[12]$, and

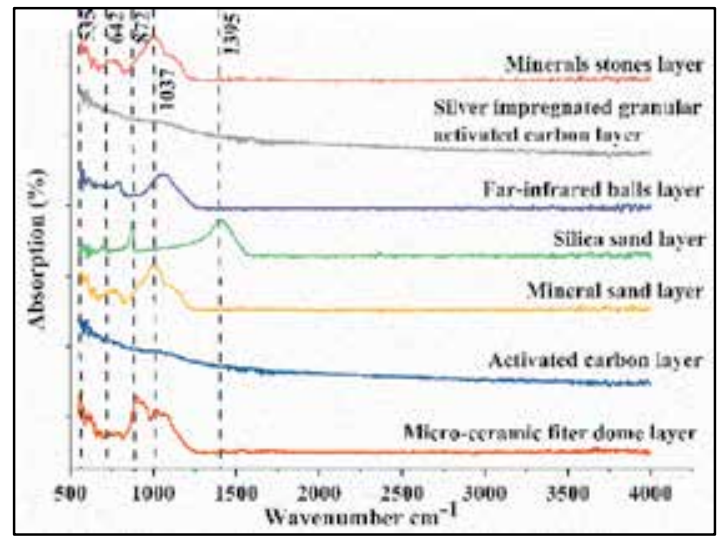

Figure 3 - FT-IR Analysis of Seven-layer Filter Unit the peak at $1087 \mathrm{~cm}^{-1}$ is due to the stretching vibration of symmetrical Si-O groups [16]. The broad peak at $3451 \mathrm{~cm}^{-1}$ is due to hydrogen bonded $-\mathrm{OH}$ as a result of surface adsorbed water molecules, and broadband around 1632 $\mathrm{cm}^{-1}$ further supports $-\mathrm{OH}$ bonding [17]. The asymmetric stretching vibration of $\mathrm{CO}_{2}$ adsorbed molecules are represented around $2375 \mathrm{~cm}^{-1}$ broad bands [20].

The XRD pattern of the top layer shows the same as the bottom layer (Figure 1i). The top layer minerals consist of silicon oxide $\left(\gamma-\mathrm{SiO}_{2}\right)$, quartz $\left(\mathrm{SiO}_{2}\right)$, and gottardiite (natural zeolite) $\left(\mathrm{Na}_{3} \mathrm{Mg}_{3} \mathrm{Ca}_{5} \mathrm{Al}_{19} \mathrm{Si}_{117} \mathrm{O}_{272}\right)$. ESEM-EDX analyses (Figure $4 \mathrm{~b}$ ) of the top layer also confirm the availability of C (21.2\%), O (44.6\%), F (1.5\%), Si $(23.5 \%), \mathrm{Al}(9.0 \%)$ and $\mathrm{P}(0.3 \%)$. FT-IR pattern of the top layer shows a similar absorption pattern like for the bottom layer (Figure 5).

Figure 6 shows the raw water and filtrate $\mathrm{Hd}$ when using the seven-layer (Figure 6a) and twolayer filter (Figure 6b) under wet and extremely wet conditions. Hd levels in the filtrate by both filters were approximately similar to that of raw water. During the wet season, Hd levels in the filtrate exceeded the respective SLS guideline values $\left(250 \mathrm{mgL}^{-1}\right)$. Hence, it was observed that the removal of Hd was not satisfactory by both the filters. Different factors could contribute to reducing the adsorbed amount of $\mathrm{Ca}^{2+}$ and $\mathrm{Mg}^{2+}$ such as; i) when the total amount of divalent cations in the raw water is below half of the number of surface charges on minerals, it limits on the adsorbed amount of cations irrespective of binding affinity, and ii) $\mathrm{Ca}^{2+}$ has a considerable binding affinity, which neutralizes a substantial fraction of surface sites than $\mathrm{Mg}^{2+}$ does, where its binding affinity becomes

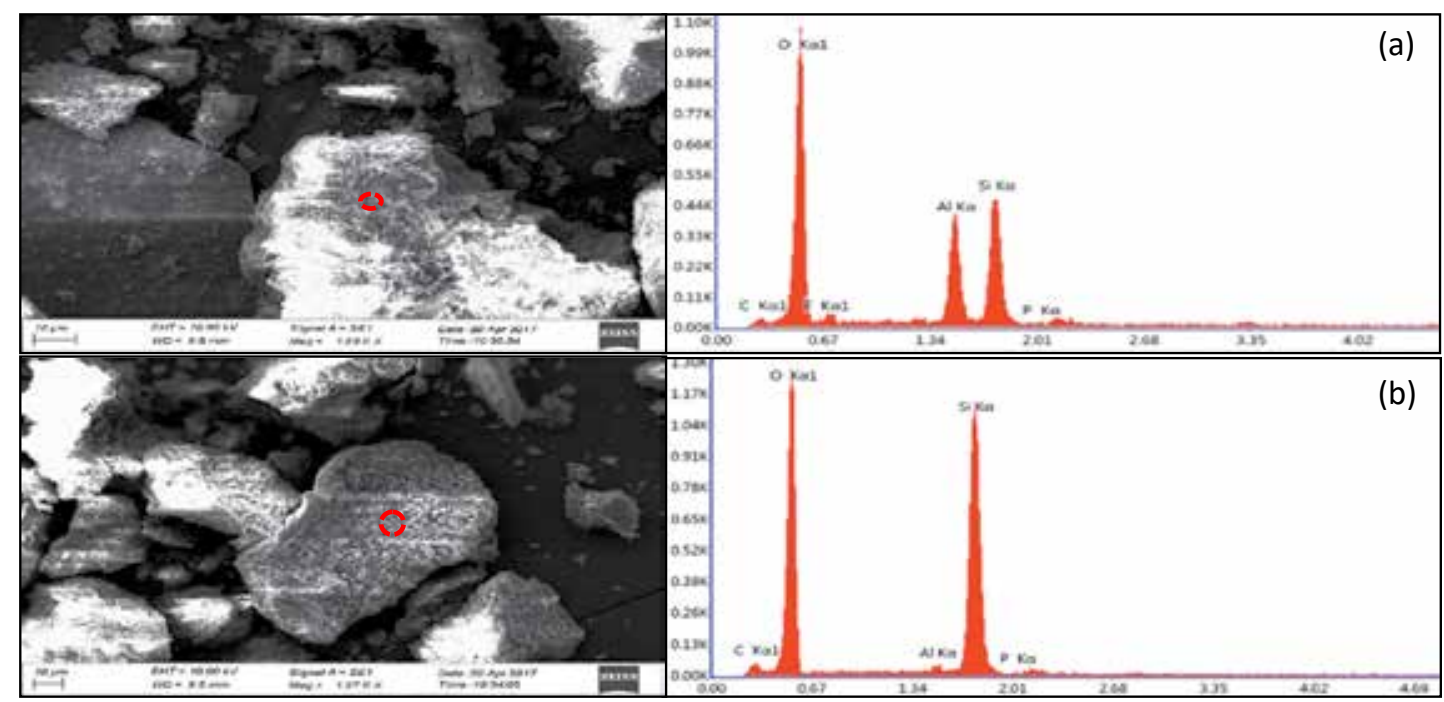

Figure 4 - SEM-EDX Analysis of Two-layer Filter (a) Bottom Layer, and (b) Top Layer 
comparatively smaller. As a result, $\mathrm{Ca}^{2+}$ and $\mathrm{Mg}^{2+}$ adsorption are reduced in magnitude, notably, in the presence of $\mathrm{Ca}^{2+}[21]$.

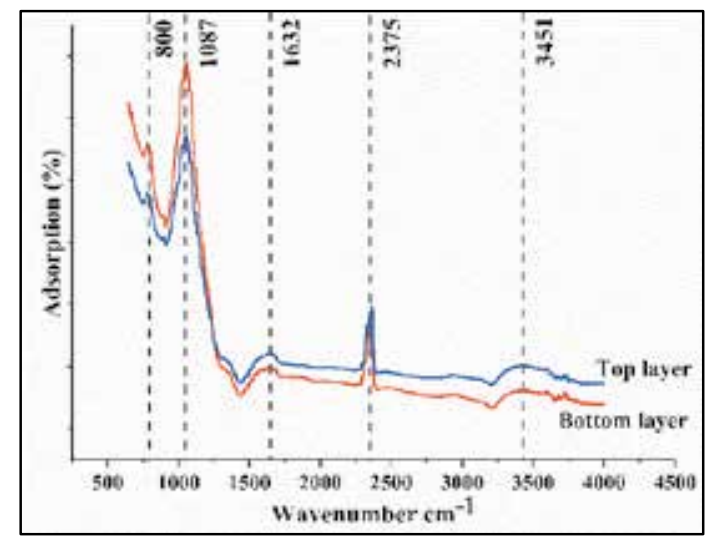

Figure 5 - FT-IR Analysis of Two-layer Filter Unit

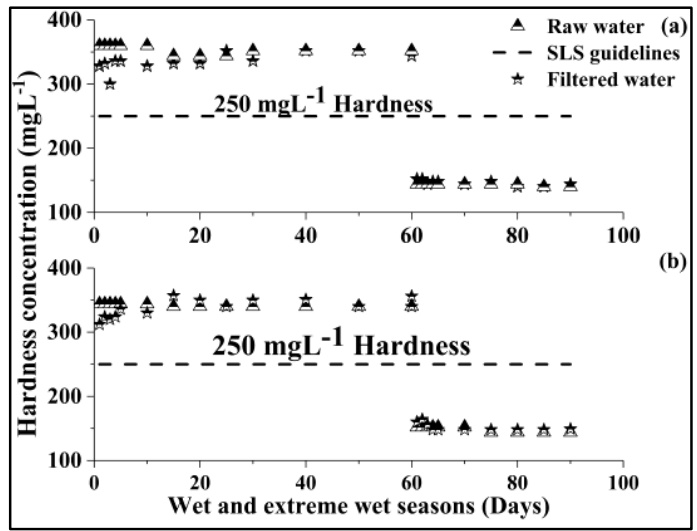

Figure 6 - Hardness Removal by (a) Sevenlayer Filter and (b) Two-layer Filter, Note: 0 to 60 days Represent Wet and 60 to 90 Days Represent Extremely Wet Seasons

Figure 7 depicts the $F$ levels present in raw water and filtrate when using a seven-layer filter (Figure 7a) and two-layer filter (Figure 7b) under wet and extremely wet conditions. It was observed that the seven-layer filter was not effective in removing F possibly due to lack of availability of adsorption sites that have the affinity for $\mathrm{F}$ adsorption. In the seven-layer filter, in general, the $\mathrm{F}$ levels in the filtrate were higher than that in the raw water (Figure 7a). This could be due to leaching of $\mathrm{F}$ from $\mathrm{F}$-contained mineral phases present in the filter media as confirmed by the XRD analysis (Figures 1c and 1g). When using the two-layer filter under the wet season $\mathrm{F}$ removal was observed. Up to 50 days, F levels in the filtrate complied with the SLS guideline value for $\mathrm{F}\left(1.0 \mathrm{mgL}^{-1}\right)$, beyond which a gradual increase in $\mathrm{F}$ level in the filtrate was observed. Higher $\mathrm{F}$ removal of efficiency was observed during the first 50 days, which could be attributed to higher retention of $\mathrm{F}$ in the two-

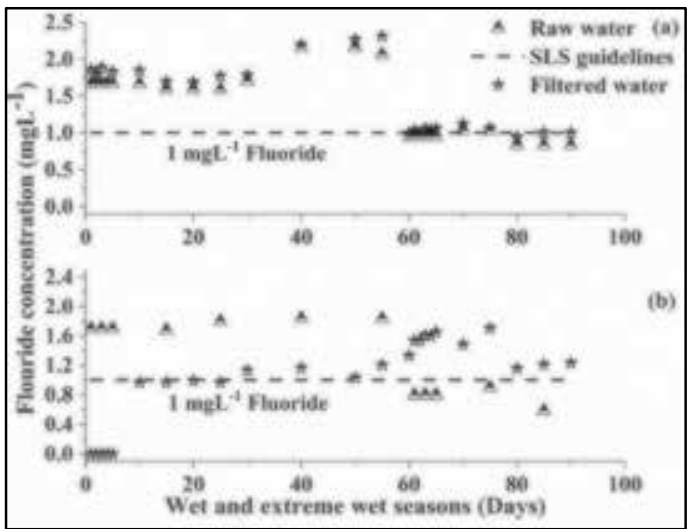

Figure 7 - Fluoride Removal by (a) Sevenlayer Filter and (b) Two-layer Filter, Note: 0 to 60 Days Represent Wet and 60 to 90 Days Represent the Extremely Wet Seasons

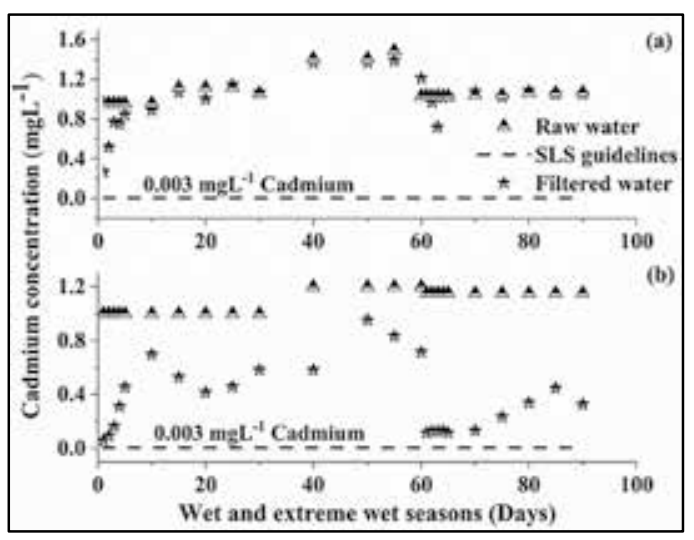

Figure 8 - Cadmium Removal by (a) Sevenlayer Filter and (b) Two-layer Filter, Note: 0 to 60 days Represent Wet and 60 to 90 Days Represent the Extremely Wet Seasons

layer filter medium, possibly due to the formation of complexes with free $\mathrm{F}$ in the solution and cations $\left(\mathrm{Al}^{3+}, \mathrm{Ca}^{2+}, \mathrm{Mg}^{2+}\right)$ present in the filter medium (e.g. $\mathrm{AlF}^{+}, \mathrm{AlF}_{2}{ }^{+}, \mathrm{AlF}_{4}, \mathrm{AlF}_{3}$ ), [5]; $\mathrm{CaF}_{2}, \mathrm{MgF}_{2}$, [4] leading to high levels of $\mathrm{F}$ removal. When using the two-layer filter under the extremely wet season, $\mathrm{F}$ level in the filtrate was higher than that in the raw water (Figure $2 b$ ). This effect could be attributed to i) saturation of $\mathrm{F}$ adsorption sites leading to poor retention of $\mathrm{F}$, and ii) detachment of $\mathrm{F}$ adsorbed on the filter medium during the wet season, resulting in elevated $F$ levels in the filtrate compared to those in the raw water.

Figure 8 illustrates the $\mathrm{Cd}$ levels present in raw water and filtrate when using the seven-layer (Figure 8a), and two-layer filters (Figure 8b) under wet and extremely wet conditions. The seven-layer filter was not effective in removing $\mathrm{Cd}$ (Figure 8a). When using the two-layer filter, 
the removal of Cd was observed under both wet and extremely wet seasons (Figure 8b). However, Cd levels in the filtrate did not comply with the SLS drinking water guideline value for Cd $\left(0.003 \mathrm{mgL}^{-1}\right)$. In comparison to the sevenlayer filter, the two-layer filter mainly comprised the clay minerals. Therefore, high removal of $\mathrm{Cd}$ with the two-layer filter could be due to the high affinity of $\mathrm{Cd}$ to the net negative charges present on clay minerals in the filter media leading to the attraction of the positively charged $\mathrm{Cd}$ in the solution. The binding coefficient of $\mathrm{Cd}^{2+}$ exceeds that of $\mathrm{Ca}^{2+}[21]$ that helps adsorb more $\mathrm{Cd}^{2+}$.

Figure 9 shows Al levels present in raw water and the filtrate when using the seven-layer filter (Figure 9a) and two-layer filter (Figure 9b) under wet and extremely wet conditions. Though both filters manifested removal of high fractions of $\mathrm{Al}$, the $\mathrm{Al}$ levels in the filtrate did not comply with the SLS drinking water guideline value for $\mathrm{Al}\left(0.2 \mathrm{mgL}^{-1}\right)$. The high removal of $\mathrm{Al}$ with the two-layer filter could be due to the net negative charges present on clay minerals in the filter media that have a higher affinity for the adsorption of $\mathrm{Al}$ leading to the attraction of positively charged Al in solution. High cationexchange capacity was indeed shown to favor fixation of Al over Ca ions [22]. In the sevenlayer filter, Fe in the Ferro-gedrite of the silica sand layer could be readily replaced by other cations [23], which in turn could increase the removal of $\mathrm{Al}$ from the solution.

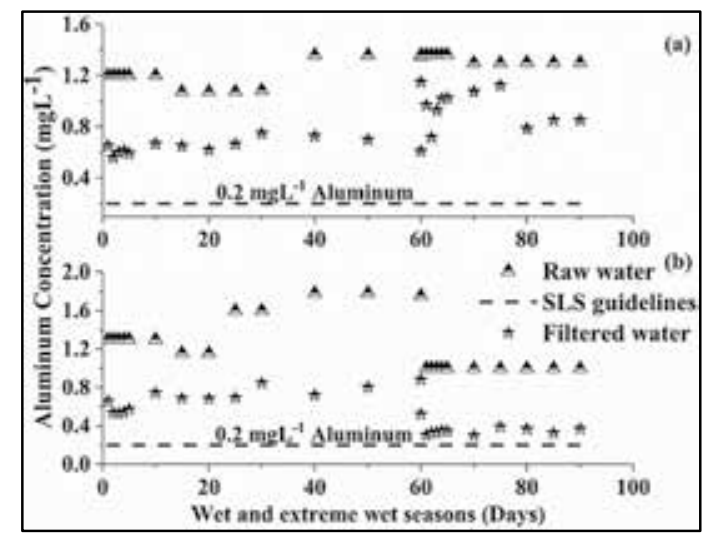

Figure 9 -Aluminum Removal by (a) Sevenlayer Filter and (b) Two-layer Filter, Note: 0 to 60 Days Represent Wet and 60 to 90 Days Represent the Extremely Wet Seasons

The XRD, ESEM-EDX, and the FT-IR analyses confirmed that different layers of the seven-layer filter composed of $\mathrm{Si}, \mathrm{Al}, \mathrm{Ca}, \mathrm{Mg}, \mathrm{Fe}$, and $\mathrm{Na}$. Therefore, unsatisfactory removal of cations present in the solution $\left(\mathrm{Ca}^{2+}, \mathrm{Mg}^{2+}, \mathrm{Cd}^{2+}, \mathrm{Al}^{3+}\right)$ by the seven-layer filter could be due to the occurrence of repulsive forces by positively charged edges in the different mineral phases of the filter media and also lack of free active sites that have affinity for adsorption of $\mathrm{Ca}^{2+}, \mathrm{Mg}^{2+}$, $\mathrm{Cd}^{2+}, \mathrm{Al}^{3+}$. In the two-layer filter, the presence of derivatives of the salicylic acid assisted higher removal of $\mathrm{Cd}$ and $\mathrm{Al}$ [24]. Moreover,the silane $(\mathrm{Si}-\mathrm{OH})$ and the carboxylic $(-\mathrm{COOH})$ groups could increase the binding affinity of $\mathrm{Cd}$ and $\mathrm{Al}$ to the filter media [25].

\section{Conclusions}

The removal of $\mathrm{Hd}, \mathrm{F}, \mathrm{Cd}$, and $\mathrm{Al}$ was investigated by a two-layer and seven-layer filter commonly used in the areas prevalent with CKDu. The $\mathrm{Hd}, \mathrm{F}, \mathrm{Cd}$, and $\mathrm{Al}$ levels present in the filtrate with both filters did not comply with the SLS drinking water quality guidelines concerning each parameter. The XRD, FT-IR, ESEM-EDX analyses revealed the presence of $\mathrm{Ca}, \mathrm{Mg}, \mathrm{F}$, and $\mathrm{Al}$ on various layers of filter media in both the filters. Such constituents retained in the filter media leach out during continuous filtration leading to an increase in levels in the filtrate. Hence, use of seven-layer and two-layer filters does not seem to be a promising solution to remove $\mathrm{Hd}, \mathrm{F}, \mathrm{Cd}$, and $\mathrm{Al}$ present in water in CKDu prevalent areas even in wet and extremely wet seasons. Therefore, the authors recommend evaluating the available potable water treatment units to ensure their suitability to supply safe potable water to people in CKDu prevalent areas.

\section{Acknowledgment}

The authors would like to express their gratitude to the Senate Research Committee (SRC) Grant of the University of Moratuwa (Grant No. SRC/ND/15/01) and the National Research Council (NRC), Sri Lanka (Grant No. 15-056) for providing necessary financial support to conduct this research.

\section{References}

1. Bandara, J. M. R. S., Senevirathna D. M. A. N., Dasanayake, D. M. R. S.V., Herath, V., Bandara, J. M. R. P., Abeysekara, T, \& Rajapaksha, K. H., "Chronic Renal Failure among Farm Families in Cascade Irrigation Systems in Sri Lanka Associated with Elevated Dietary Cadmium Levels in Rice and Freshwater Fish (Tilapia)", Environ Geochem Health, Vol. 30, January, 2008, pp. $465-478$.

2. Chandrajith, R., Nanayakkara, S., \& Itai, K., Aturaliya T. N., Dissanayake C. B., Abeysekera T., Harada K., Watanabe T., Koizumi A. “Chronic Kidney Diseases of Uncertain Etiology 
(CKDue) in Sri Lanka: Geographic Distribution and Environmental Implications", Environ Geochem Health, Vol. 33, No. 3, June, 2011, pp. 267278.

3. Jayatilake, N., Mendis, S., Maheepala, P., \& Mehta, R. F., "Chronic Kidney Disease of Uncertain Aetiology: Prevalence and Causative Factors in a Developing Country", BMC Nephrol., Vol. 14, No. 180, August, 2013, pp. 1-13.

4. Dharma-wardana, M. W. C., Amarasiri, S. L., Dharmawardene, N. \& Panabokke, C. R., “Chronic Kidney Disease of Unknown Aetiology and Ground-water Ionicity; A Study Based on Sri Lanka", Environ Geochem Health, Vol. 31, No.2, April, 2015, pp. 221-231.

5. Ileperuma, O. A., Dharmagunawardhane, H. A. \& Herath, A. P. R. P., "Dissolution of Aluminium from Sub-standard Utensils under High Fluoride Stress: A Possible Risk Factor for Chronic Renal Failure in the North-Central Province", I Natl Sci Found of Sri Lanka, Vol. 3, No. 37, September, 2009. pp. 219-222.

6. Cittanova, M. L., Leblanc, I., Legendre, C., Mouquet, C., Riou, B., \& Coriat, P., "Effect of Hydroxyethyl Starch in Brain-dead Kidney Donors on Renal Function in Kidney-Transplant Recipients", Lancet, Vol. 348, No. 9042, December, 1996, pp. 1620-1622.

7. Wasana, H. M. S., Aluthpatabendi, D., Kularatne, W. M. T. D., Wijekoon, P., Weerasooriya, R., \& Bandara, J., "Drinking Water Quality and Chronic Kidney Disease of unknown Etiology (CKDu): Synergic Effects of Fluoride, Cadmium and Hardness of Water", Environ Geochem Health, Vol. 38, No.1, February, 2016, pp.157-168.

8. Hady, H. A. E., "Syntheses and Antimicrobial Activity of some New Thiohydantoin and Thiazole Derivatives", Der Pharma Chemica, Vol. 4, No.6, June 2012, pp. 2202-2207.

9. Souza, M. A., Johann, S., Lima, L. A. R. S., Campos, F. F., Mendes, I. C., Beraldo, H., Fagundes, E. M. S., Cisalpino, P. S., Rosa, C. A., Alves, T. M. A., de Sá, N. P., \& Zani, C. L. "The Antimicrobial Activity of Lapachol and its Thiosemicarbazone and Semicarbazone Derivatives", Mem Inst Oswaldo Cruz, Vol. 108, No. 3, May, 2013, pp. 342-351.

10. Brooks, A. S., Rozenwald, M. N., Geohring, L.D., Lion, L. W., \& Steenhuis, T. S., "Phosphorus Removal by Wollastonite: A Constructed Wetland Substrate", Ecol Eng., Vol. 15, June, 2000, pp. 121-132.

11. Kumanan, M., Sathya, G. Nandakumar, V., \& Berchmans, I. J. "Extraction of Potash from kFeldspar Mineral by Acid and Molten Salt
Leaching Processes", IASET: IJMMCE, Special Edition, July, 2016, pp. 1-10.

12. Mu“ller, C. M., Pejcic, B., Esteban, L., Piane, C. D., Raven, M., \& Mizaikoff, B., "Infrared Attenuated Total Reflectance Spectroscopy: An Innovative Strategy for Analyzing Mineral Components in Energy Relevant Systems", Scientific report, Vol. 4, October, 2014, pp. 6764.

13. Yu, J., Yang, M.,Lin, T., Guo, Z., Zhang, Y., Gu, J., \& Zhang, S., "Effects of Surface Characteristics of Activated Carbon on the Adsorption of 2Methylisobornel (MIB) and Geosmin from Natural Water", Sep. Purif. Technol., Vol. 56, January, 2007, pp. 363-370.

14. Mishra, M. K., "Fourier Transform Infrared Spectrophotometry Studies of Chromium Trioxide-Phthalic Acid Complexes", Chem. Sci. Trans., Vol. 5, No. 3, May, 2016, pp. 770-774.

15. Sivakumar, S., R., Ravisankar, R., Raghu, Y., Chandrasekaran, A., \& Chandramohan, J., "FTIR Spectroscopic Studies on Coastal Sediment Samples from Cuddalore District, Tamilnadu, India", IJACS, Vol. 1, December, 2012, pp. 40-46.

16. Elhefnawy. O., \& Elabd, A. A., "Natural Silica Sand Modified by Calcium Oxide as a New Adsorbent for Uranyl Ions Removal from Aqueous Solutions", Radiochim. acta, Vol. 105, No. 10, January, 2017, pp. 821-830.

17. Akl, M. A., Aly, H. F., Soliman, H. M. A., AbdElrahman, A. M. E., \& Abd-Elhamid,A. I., "Preparation and Characterisation of Silica Nanoparticles by Wet Mechanical Attrition of White and Yellow Sand", I Nanomed. Nanotechnol., Vol. 4, No. 183, November, 2013, pp. $1-14$.

18. Ranjbar, B., Afshar, S., Kakanejadifard, A., Khajeh, K., Naderi-Manesh, H., Hassani, L., \& Alizadeh, N., "Effects of Glyoxime and Dichloroglyoxime on Lysozyme: Kinetic and Structural Studies". Asian J. Biochem., Vol. 1, No. 2, 2006, pp. 153-161.

19. Lippincott, E. R., Valkenburg, A. V., Weir, C. E., \& Bunting, E. N., "Infrared Studies on Polymorphs of Silicon Dioxide and Germanium Dioxide", J Res Natl Bur Stand, Vol. 61, No. 1, July, 1958, pp. 61-70.

20. Seiferth, O., K. Wolter, K., Dillmann, B., G. Klivenyi, G., Freund, H. J., Scarano, D.,Zecchina, A., "IR Investigations of $\mathrm{CO} 2$ Adsorption on Chromium Surfaces: Cr2O3 (0001)/Cr (110) Versus Polycrystalline A-Cr2O3", Surf. Sci., Vol. 421, November, 1999, pp. 176-190.

21. Rytwo, G., Banin, A., \& Nir, S., "Exchange Reactions in the Ca-Mg-Na-Montmorillonite 
System", Clays Clay Miner., Vol. 44, No. 2, June, 1996, pp. 276-285.

22. Buscher, P., Koedam, N., \& Van Speybroeck, D., "Cation-Exchange Properties and Adaptation to Soil Acidity in Bryophytes", New Phytol., Vol. 115, November, 1990, pp. 176-186.

23. Schumacher, J. C., "Empirical Ferric Iron Corrections: Necessity, Assumptions, and Effects on Selected Geothermobarometers", Mineral Mag., Vol. 55, March, 1991, pp. 3-18.

24. Ahmaruzzaman, M. \& Gupta, V. K., "Rice Husk and Its Ash as Low-Cost Adsorbents in Water and Wastewater Treatment", Ind. Eng. Chem. Res., Vol. 50, No. 24, October,2011, pp. 1358913613.

25. Wong, K. K., Lee, C. K., Low, K. S. \& Haron, M. J., "Removal of $\mathrm{Cu}$ and $\mathrm{Pd}$ by Tartaric Acid Modified Rice husk from Aqueous Solutions", Chemosphere, Vol. 50, August, 2002, pp. 23-28. 